\title{
NON-PROFIT ORGANIZATIONS DENSITY, SOCIALLY VULNERABLE CATEGORIES AND ECONOMICAL DEVELOPMENT FROM VOLUNTARY AND GOVERNMENT FAILURE THEORIES PERSPECTIVE
}

\author{
Nemțeanu Marcela-Sefora1, Coita Dorin-Cristian², Tarcza Mihaela-Teodora ${ }^{3}$ \\ ${ }^{1}$ Marketing Department, Faculty of Economics and Business Administration; \\ Babeș Bolyai University, Cluj-Napoca, Romania. \\ 2,3. Management and Marketing Department, Faculty of Economic Sciences, \\ University of Oradea, Oradea, Romania \\ seforanemteanu@gmail.com \\ dorincoita@gmail.com \\ teodoratarcza@gmail.com
}

\begin{abstract}
Non-profit organizations have an important role in democracy development, volunteering and in providing support for disadvantaged social categories whose access to social and medical services or to goods of current necessity is reduced. Recent studies prove that local social sustainability correlates to non-profit organizations density at a local or regional level. Previous research encompasses two directions for the study of the role of non-profit organization the first is supported by the Theory of Government and Market Failure, and the second by the Theory of Voluntary Failure. The Theory of Government and Market Failure starts from the assumption that non-profit sector developed as a result of the need for social services provided to categories of population for whom government and market failed to provide to an affordable price or constantly. The Theory of Voluntary Failure starts from the assumption that non-profit sector plays the most important role in case of socio-economic crises or catastrophes but for organizations to perform well the support of the state is needed. This research aim is the assessment of non-profit density correlation to economic development and percentage of the social vulnerable population in Romania. This paper brings theoretical contribution to the study of the non-profit density, to the Theory of Government and Market Failure and to the Theory of Voluntary Failure and practical implications to an emerging economy.
\end{abstract}

Keywords: non-profit organizations density, social vulnerable categories, economic development, GDP per capita, Voluntary Failure Theory, Government Failure Theory.

JEL Classification: 131, I38, L31.

\section{Introduction}

The non-profit sector in Romania in its current form has developed mainly after 1989, since then experiencing an exponential development (Sana, 2014; Nemțeanu \& Tarcza, 2016). However, non-profit organizations in Romania are not yet uniformly developed, their development being facilitated or limited depending on the local policies and the degree of development (Andersen et al., 2017) but also on the possibility of correlating the demand for social support of vulnerable categories with the supply of these entities that take over managerial models and 
methods to create a social impact (Ballestros \& Gatignon, 2019). In this context, the study of non-profit organizations, their development and how they meet the needs of the society, is still at an exploratory level, requiring much more research to contribute to the clear dimensioning of the non-profit sector but also in terms of the factors that contribute to its development (Andersen et al., 2017).

Previous academic research highlights two broad directions in assessing the role of non-profit organizations, namely an approach to the Government and Market Failure Theories (Salamon, 1987) that start from the assumption that the non-profit organizations meet the needs of social categories that cannot afford services or for that there is no acceptable supply of services and goods. The second approach is the Voluntary Failure Theory (Salamon, 1987), or interdependence (Săveanu, 2011) which starts from the presumption that the non-profit organizations develop only when they are supported, their development being directly proportional to the support from part of the state. Through this paper we aim to analyze the premises for the development of non-profit organizations in the context of an emerging economy such as Romania, through this objective covering a gap in the research on exploring the theoretical implications of nonprofit organizations based on data covering the entire situation of the non-profit sector. The paper includes a review of the literature, a development of the research methodology, based on the Correlation Analysis by Pearson's coefficient and a section of discussions and conclusions of the research.

\section{Literature review}

\subsection{Government and Market Failure Theories and non-profit sector development}

The concept of non-profit density has received widespread interest in the last decade, being calculated as the percentage of non-profit organizations in terms of population (Kim, 2013; Lecy \& Van Slyke, 2013; Van Puyvelde \& Brown, 2016; Witesman, 2016). However, the increase in non-profit density is influenced by a wide variety of stakeholders (Van Puyvelde \& Brown, 2016). Previous research conducted between different regions in the United States shows that potential beneficiaries play a key role in increasing the density of the non-profit organizations, which is higher where social disparities are high and social inequalities and problems are pronounced in the community, and the need for social services is high (Kim, 2013). Community heterogeneity is positively associated with the development of the density of non-profit organizations being associated with fragmented and decentralized government leadership in another study conducted in the US regions (Jeong \& Cui, 2020). Thus, we can conclude that the role of the non-profit organizations is to meet the precarious social needs covered by the government or the market, which confirms Government and Market Failure Theory assumptions.

The research at the EU level highlights an indicator in the analysis of vulnerable categories of the population, namely the population at risk of social exclusion (Eurostat, 2020a). This risk can be due to a high degree of poverty, lack of employment opportunities, access to basic services and goods and includes various demographic categories (Kwilinski et al., 2020). Social exclusion population is represented of people found at risk of poverty (Eurostat, 2020b). Different countries have different politics on combatting social exclusion, one of the interventions consisting in providing social aid for guaranteed minimum wage 
(Stroe \& Cojanu, 2017). State intervention is often associated to non-profit organizations aid providing with services and products, donations and help for persons at risk of poverty (Schinnerl \& Greiling, 2019). Based on the previous arguments we conclude that:

H1: Non-profit density growth is correlated to social aid for guaranteed minimum wage.

\subsection{Voluntary Failure Theory and non-profit sector development}

Voluntary Failure Theory or Interdependence Theory (starts from the premise that the non-profit organizations are more developed where there is higher economic development and they receive support from the government through funding or other leverage (Lecy \& Van Slyke, 2013).

From Voluntary Failure perspective, non-profit organizations play the most important role in cases of disasters and socio - economic crises (O'Donovan, 2015) but in order to achieve their objective they depend on the support of state institutions and companies (Săveanu, 2011). The non-profit density is according to previous results (Lecy \& Van Slyke, 2013) positively influenced by the government support that can come through funding. Starting from the highlighted results of the research, we suggest the following hypothesis:

H2: Non-profit density is correlated with economic development.

\subsection{Economic development and social exclusion risk}

The gross domestic product is an internationally relevant indicator in measuring the economic development and the population welfare (Clarke \& Islam, 2003). On the other hand, the risk of social exclusion is an indicator of the estimation of the lack of welfare and impoverishment of the population in an analyzed region (Kwilinski et al., 2020).

The economic development contributes to the reduction and even eradication of poverty among the population over time and, respectively, to the reduction of the number of people in social exclusion (Sinding, 2009; Cremin \& Nakabugo, 2012). A recent concept that aims to reduce the percentage of the population in social exclusion being the Sustainable Development Goals (UN, 2014; Hák et al., 2016), taken over internationally based on the orientation towards efforts for economic development in different sectors (Cremin \& Nakabugo, 2013). In European Union social exclusion is defined as people at risk of poverty if they have a disposable income below the $60 \%$ of the national medial equivalized disposable income (Eurostat, 2020b). In Romania people with below guaranteed income benefit of social aid for guaranteed minimum wage the number of beneficiaries differing from county to county according to National Agency for Payments and Social Inspection (2019) data. Based on the presented arguments we propose the hypothesis: H3: Economic development is correlated with social aid for minimum wage.

\section{Research Methodology}

\subsection{Research Context}

Romania is a developing economy (Dabija \& Bejan, 2018), with a past in the communist regime (Nemțeanu \& Dabija, 2020b), in which, democracy and in aftermath non-profit organizations have developed significantly in recent decades (Coita, 2008; Andersen et al., 2017). Non-profit organizations became providers for social services, services for youth, educational, medical, civic, entertainment, 
consumer protection, animal protection, religious and other services contributing to community development and civic engagement (Andersen et al., 2017).

\subsection{Research methodology}

This research was conducted starting from secondary Eurostat databases (2020a; 2020b), the Register of Non-profit Organizations (MJR, 2019) and the Statistical Yearbook of Romania (National Institute of Statistics, 2019). Statistical analyzes were performed based on the distribution of indicators: non-profit organizations density, GDP / capita and Social Exclusion Risk population in the 8 regions of Romania as defined by the European Commission (Eurostat, 2020a). In Romania there are currently over 100,000 non-profit organizations; at the time of the analysis there are at national level a number of 119,430 entities in this sector.

Figure no. 1. Non-profit organizations Density at 1000 inhabitants Romania $(\mathrm{N}=119.430)$

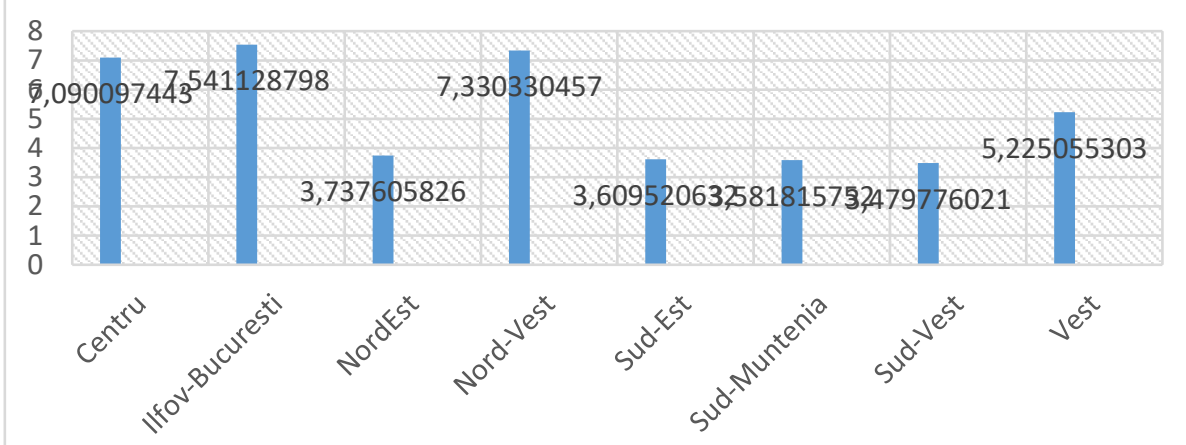

Source: Data processed by the authors of the research taken from the Register of non-profit organizations (MJR, 2019), and the Statistical Yearbook (2020) for the data regarding the Romanian population in 2019.

Based on the processed data. As can be seen in figure no. 1, the llfov-Bucharest region, North-West and Center region have a number of over 7 non-profit organizations per 1000 inhabitants. At the opposite pole there is the Southeast region with only 3.6 non-profit organizations per 1.000 inhabitants.

Figure no. 2. Non-profit organizations at 1000 inhabitants per county, $\mathrm{N}=42$

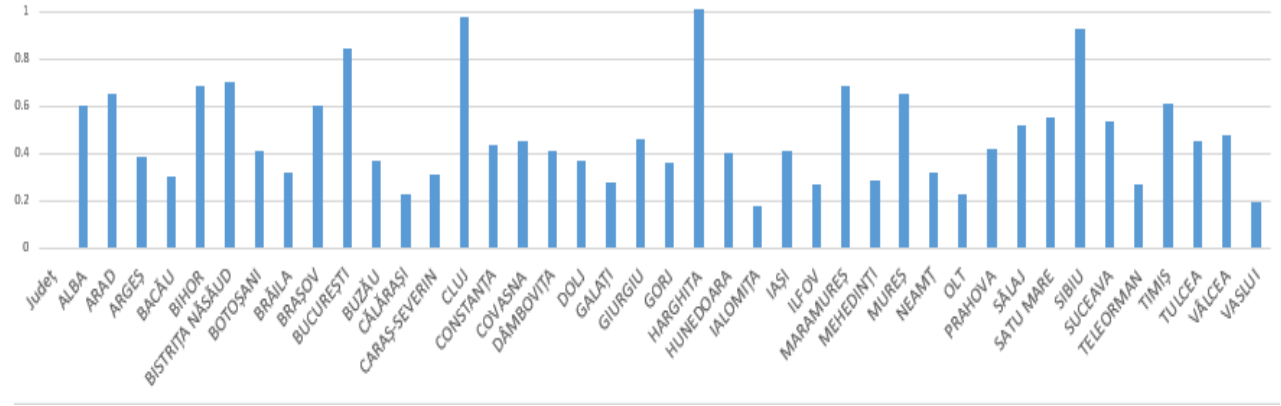


Source: Data processed by the authors of the research taken from the Register of non-profit organizations (MJR, 2019), and the Statistical Yearbook (2020) for the data regarding the

Romanian population in 2019.

As it is presented in Figure no. 2 counties with highest density at 1.000 inhabitants are Cluj and Harghita, followed by Sibiu, these counties having close to one organization at 1.000 inhabitants. The lowest non-profit organizations density is found in lalomița and Vaslui with 2 organizations at 10.000 inhabitants.

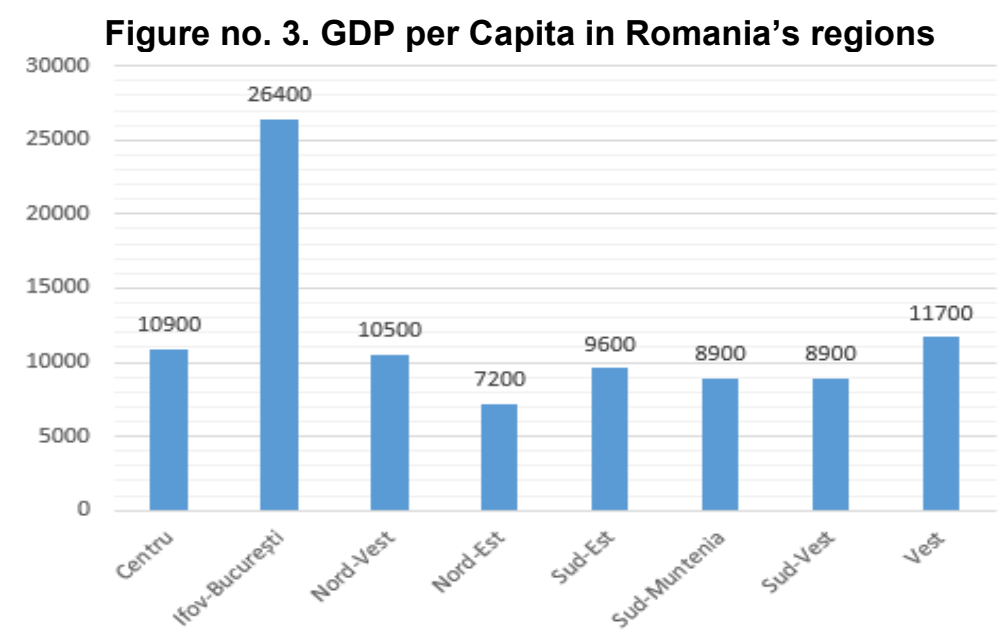

Source: Eurostat (2020a) Regions and Cities Illustrated (RCI). Gross domestic product (PPS per inhabitant), 2019.

https://ec.europa.eu/eurostat/cache/RCI/\#?vis=nuts2.economy\&lang=en accessed 03.03.2020

A relevant indicator in this research related to non-profit organizations density is GDP / capita understood as an indicator of regional economic development (Eurostat, 2020b), As can be seen in figure no. 3, the llfov-Bucharest region shows a significantly more alert economic development compared to other regions, being followed by the North-West region, respectively by the Western region.

Figure no. 4. GDP per Capita in Romania's counties, $\mathrm{N}=42$

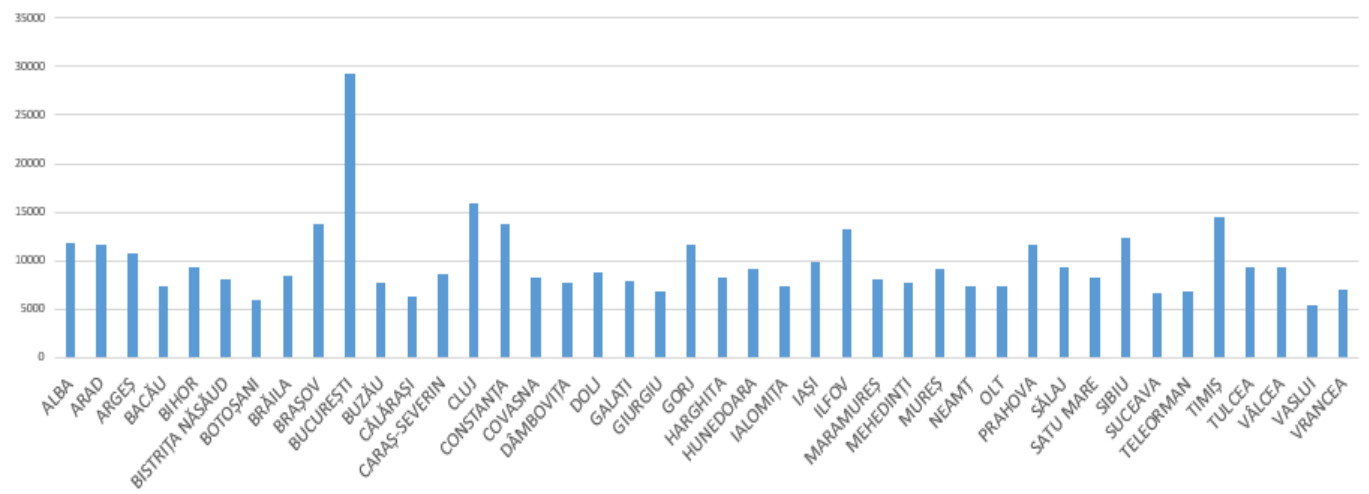


Source: National Commision for Strategy and Prognosis, 2021.Prognosis 2020-2024 in teritory, GDP per Capita 2019.

https://cnp.ro/wp-content/uploads/2021/07/PROGNOZA_2020_2024_in_profil_teritorial.pdf

According to figure no. 4 GDP per capita is highest in Bucharest $(29.175$ Euro/inhabitant) followed by Cluj (15.890 Euro/inhabitant), Brașov (13.826 Euro/inhabitant) and Constanța (13.741 Euro/inhabitant). The lowest value for GDP per capita is found in Vaslui (5.462 Euro/inhabitant) followed by Botoșani (5.972 Euro/inhabitant) and Călărași (6.300 Euro/inhabitant).

Figure no. 5. People at risk of poverty or social exclusion in European Union

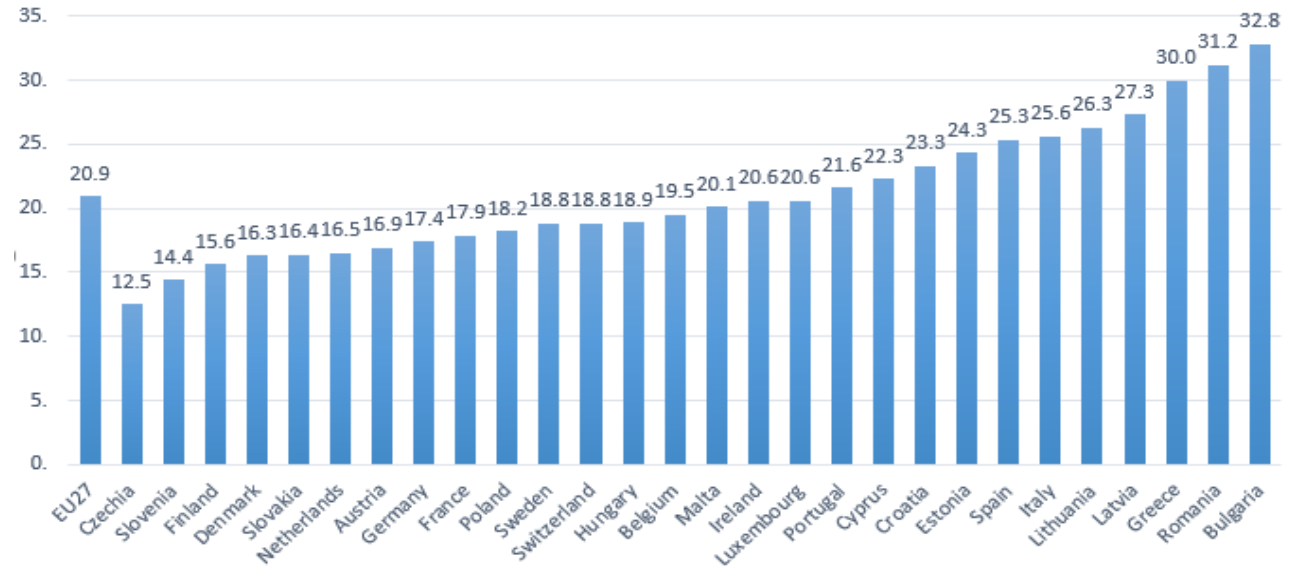

Source: Eurostat (2020b),

https://ec.europa.eu/eurostat/databrowser/view/sdg_01_10/default/table?lang=en

According to Eurostat (2020b) data, as it can be observed in figure no. 5, Romania has the second highest rate of people at risk of poverty or social exclusion with a rate of $31.2 \%$ in European Union, Bulgaria representing the country in UE with the highest rate of $31.8 \%$. The two countries have with more than $10 \%$ more population in risk of poverty and social exclusion than the average of European Union that is of $20.9 \%$.

Figure no. 6. People at risk of poverty or social exclusion at $\mathbf{1 . 0 0 0}$ inhabitants 


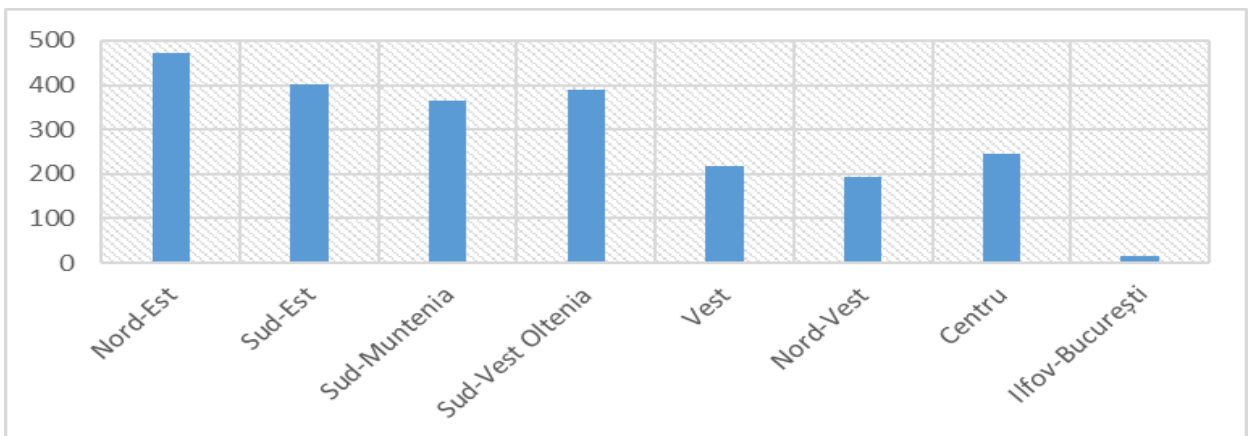

Source: Eurostat (2020b). People at risk of poverty or social exclusion by NUTS 2 regions, 2019 https://ec.europa.eu/eurostat/databrowser/view/tgs00107/default/table?lang=en

As can be seen in figure no. 6, in the North-East Region the percentage of the population at risk of social exclusion is over $47 \%$. At the opposite pole, the IlfovBucharest region includes the smallest population rate at risk of social exclusion.

\section{Figure no. 7. Number of beneficiaries of Social Aid for Guaranteed Minimum Income, $\mathrm{N}=42$}

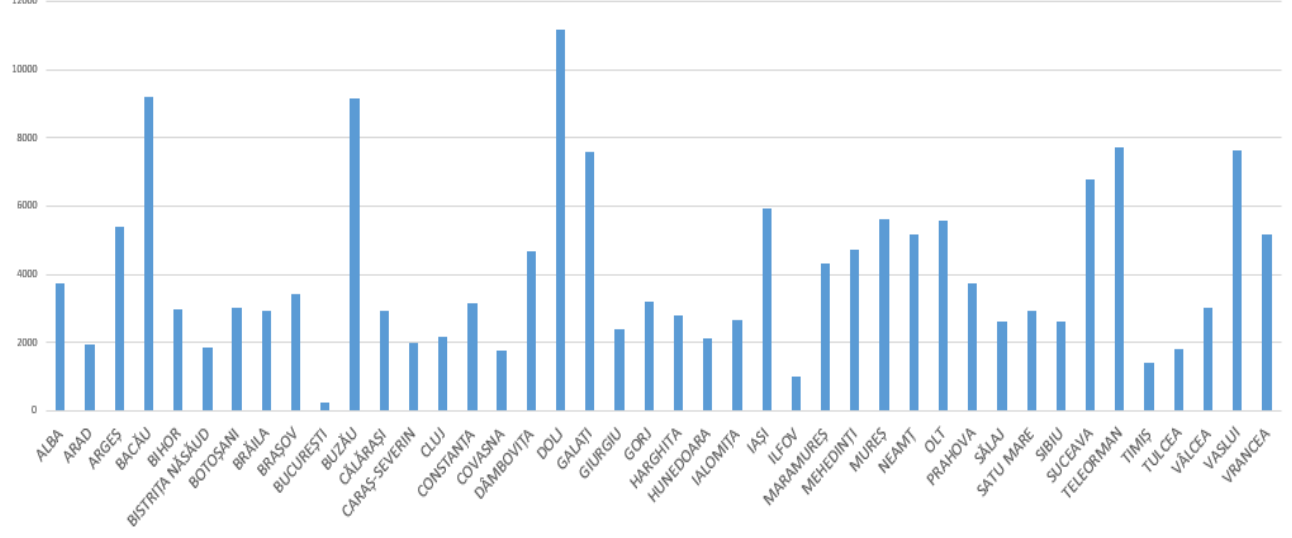

Source: National Agency for Payments and Social Inspection. 2019. Report on Social Aid (Guaranteed Minimum Income) December 2019.

\section{file:///C:/VMG_Decembrie_2019.pdf}

In combatting social exclusion, social aid is provided to personas that are resident in Romania and have the net monthly income is lower than guaranteed minimum income (Stroe \& Cojanu, 2017). According to the public data of National Agency for Payments and Social Inspection (2019) presented in figure no. 7 the counties with highest number of beneficiaries of social aid are Dolj with 11.188 beneficiaries followed by Bacău with 9.176 beneficiaries and Buzău with 9.164. Counties with the lowest number of social aids for guaranteed minimum income are Bucharest with 240 beneficiaries followed by Ilfov with 1.023 beneficiaries and Timiș with 1.414 beneficiaries. 


\subsection{Correlation Analysis results}

The purpose of the research consists in the emphasizing of the linkage between non-profit organizations density to economic development and social exclusion. The research methodology is secondary data analysis.

Selected data was the number of non-profit organizations per county according to the Register of Non-profit Organizations (MJR, 2019), GDP per capita according to National Commission for Strategy and Prognosis, (2021) and social aid for guaranteed minimum wage per counties for December 2019 according to National Agency for Payments and Social Inspection, (2019).

Selected data were processed using the SPSS20 program to test the hypotheses by parametric Correlation analysis based on Pearson's coefficient (Malhotra \& Birks, 2006). Pearson Correlations has been previously used in analysis of the linkage of GDP per capita and other indicators (Peck \& Pressman, 2013).

Table. no. 1. Correlations analysis results $\mathrm{N}=42$

\begin{tabular}{llrrr}
\hline Variables & & NPODensity & GDPperCapita & SAGMIB \\
\hline \multirow{4}{*}{ NPODensity } & Pearson Correlation & 1 & $.504^{* *}$ & $-.400^{* *}$ \\
& Sig. (2-tailed) & & .001 & .009 \\
& $\mathrm{~N}$ & 42 & 42 & 42 \\
& Pearson Correlation & $.504^{* *}$ & 1 & $-.437^{* *}$ \\
GDPperCapita & Sig. (2-tailed) & .001 & & .004 \\
& $\mathrm{~N}$ & 42 & 42 & 42 \\
& Pearson Correlation & $-.400^{* *}$ & $-.437^{* *}$ & 1 \\
SAGMIB & Sig. (2-tailed) & .009 & .004 & \\
& $\mathrm{~N}$ & 42 & 42 & 42
\end{tabular}

Note: ${ }^{* *}$. Correlation is significant at the 0.01 level (2-tailed). NPODensity - Non-profit organizations density; GDP per Capita - Gross Domestic Product per capita; SAGMIB Social ai for Guaranteed minimum Income Beneficiaries.

The results of the correlation analysis show that non-profit organization density is inverse proportional correlated with social aid for guaranteed minimum income number of beneficiaries $(0.400 ; p$-value $<0.01)$ Hypothesis 1 being accepted of negative values. We can say that where the need for social aid is higher and social exclusion is higher, the development of the sector is lower, the link between the two variables being inversely proportional. These results lead to the acceptance of the $\mathrm{H} 1$ hypothesis, stating that the results regarding the meaning of influence are surprising and in opposition to the assumptions of the Market and Government Failure Theory. Regarding the link with GPD per Capita, the regional economic development is positively correlated with the density of non-profit organizations (proportional $(0.504 ; p$-value $<0.01)$, so we can conclude that the $\mathrm{H} 2$ hypothesis is accepted. At the county level there is a strong interdependence between the economic development and the growth of the non-profit sector, the results confirming theoretical assumptions of previous research (Salamon, 1987; Săveanu, 2011; Nemțeanu \& Dabija, 2020a). The linkage of GDP per Capita and social aid 
for guaranteed minimum income is inverse proportional $(-0.436 ; p$-value $<0.01)$ which leads to the acceptance of hypothesis $\mathrm{H} 3$ confirming similar research results that underline the negative linkage between economic development and social exclusion (Sinding, 2009; Cremin \& Nakabugo, 2012).

\section{Conclusions}

The present paper brings contributions on Government and Market Failure Theory respectively Voluntary Failure Theory, contributing to the understanding of the implications of these theories in terms of non-profit organizations density in relation to the economic development through GDP / capita and social aid for guaranteed minimum wage number of beneficiaries.

The practical implications of the paper are to emphasize the importance of the non-profit organization density indicator in relation to other national indicators in order to correlate the development need of the non-profit sector to fight against social problems such as the risk of social exclusion that may manifest in various forms. The results show that non-profit organizations are positively correlated to economic development measured by GDP per capita which is a confirmation to previous research on the interdependence of non-profit sector to economic and state institutes.

The problem of social exclusion is more prominent in Romania, the percentage of population affected by poverty being higher that European Union average. The development of non-profit sector is indirect proportional to the number of people that need financial support from state institutions as being in poverty risk and social exclusion. The solution for the regions and counties more affected by poverty in Romania could be the development of non-profit organizations and raise of non-profit density with the support of state institutions and business entities.

The limits of the research consist in the strictly local approach to the issue, and the evaluation of a small number of indicators. Future directions of research may complement the research in order to assess other factors that generate such an acute shortage of non-profit organizations in regions with a significant percentage of social aid for guaranteed minimum income beneficiaries as an indicator of social exclusion.

\section{References:}

1. Andersen, S., Angi, D., Barna, C., Burada, V., Burean, T., Constantinescu, S., Dumitrescu, V., Kivu, M., Nicovescu A., Opincaru, S.I., Pop, A., Radu, B., 2017. România 2017 Sectorul Neguvernamental. Profil, Tendințe, Provocări. București: Fundația pentru Dezvoltarea societății Civile.

2. Ballestros, L. and Gatignon, A., 2019. The relative value of firm and nonprofit experience: Tackling large-scale social issues across institutional contexts. Strategic Management Journal, 40(4) pp.631-657.

3. Clarke, M., Islam, S. M., 2003. Measuring social welfare: application of social choice theory. The Journal of Socio - Economics, 32(1), 115. doi:10.1016/s1053-5357(03)00010-6.

4. Cremin, P., Nakabugo, M. G., 2012. Education, development and poverty reduction: A literature critique. International Journal of Educational Development, 32(4), 499-506. doi:10.1016/j.jjedudev.2012.02.0 
5. Coita, D.C., 2008. Marketingul organizațiilor nonprofit. București: Editura Academiei Române.

6. Dabija, D.C. and Bejan, B.M., 2018. Sustainability reporting of grocery retailers on an emerging market. In: Pleșea, D., Vasiliu, C., Murswieck, A., Pamfilie, R., Dinu, V., Tăchiciu, L., Olaru, M. (Eds.). Fourth BASIQ International Conference on New Trends in Sustainable Business and Consumption. Heidelberg, Germany, 11-13 June 2018. Bucharest: Editura ASE. (pp.611-619).

7. Eurostat, 2020a. Regions and Cities Illustrated (RCI). Gross domestic product (PPS per inhabitant), 2019. [online] Available at

<https://ec.europa.eu/eurostat/cache/RCl/\#?vis=nuts2.economy\&lang=en> [Accessed in 30.03.2020].

8. Eurostat, 2020b. People at risk of poverty or social exclusion [online] Available $<$ https://ec.europa.eu/eurostat/databrowser/view/tgs00107/default/table?la $\mathrm{ng}=\mathrm{en}>$ [Accessed in 30.03.2020].

9. Hák, T., Janoušková, S., Moldan, B., 2016. Sustainable Development Goals: A need for relevant indicators. Ecological Indicators, 60, 565573. doi:10.1016/j.ecolind.2015.08.003.

10. Jeong, J., Cui, T.S., 2020. The Density of Non-profit Organizations: Beyond Community Diversity and Resource Availability. Voluntas, 31, 213226. https://doi.org/10.1007/s11266-019-00175-8.

11. Kim, M., 2013. Socioeconomic Diversity, Political Engagement, and the Density of Non-profit Organizations in U.S. Counties. The American Review of Public Administration, 45(4), pp. 402416. doi:10.1177/0275074013504616.

12. Kwilinski, A., Vyshnevskyi, O., Dzwigol, H., 2020. Digitalization of the EU Economies and People at Risk of Poverty or Social Exclusion. Journal of Risk and Financial Management. 13(7):142. https://doi.org/10.3390/jrfm13070142.

13. Lecy, J.D., Van Slyke, D.M., 2013. Non-profit Sector Growth and Density: Testing Theories of Government Support, Journal of Public Administration Research and Theory, 23(1), pp. 189214, https://doi.org/10.1093/jopart/mus010.

14. MJR, 2019. Register of nongovernmental organizations. Ministerul Justiției. [online] Available at <http://www.just.ro/registrul-national-ong/> [Accessed 12 Decembrie 2019].

15. Malhotra, N. K., Birks, D. F., 2007. Marketing Research. An Applied Approach, Third Edition. London: Prentice Hall.

16. National Institute of Statistics. 2019. Romanian Statistical Yearbook.

17. National Agency for Payments and Social Inspection, 2019. Report on Social Help (Guaranteed Minimum Income) December 2019. [online] <file:///C:/VMG_Decembrie_2019.pdf> [Accessed in 03.02.2021].

18. Nemțeanu, M.S., Dabija, D.C., 2020a. Best practices of nongovernmental organisations in combatting Covid-19. In: R. Pamfilie, V. Dinu, L. Tăchiciu, D. Pleșea, C. Vasiliu eds. 6th BASIQ International Conference on New Trends in Sustainable Business and Consumption. Messina, Italy, 4-6 June 2020. Bucharest: ASE. 
19. Nemteanu, M.S., Dabija, D.C., 2020b. The Influence of Heavy Work Investment on Job Satisfaction and Turnover Intention in Romania. Amfiteatru Economic, 22(14), pp. 993-1013.

20. Nemțeanu, S.M., Tarcza, T.M., 2016. Volunteers Trust in Organizational Mission, Leadership and Activities Efficiency", Analele Universităţii din Oradea, 25(1), pag. 995-1002; ISSN 1222 - 569X, ISSN 1582 - 5450.

21. O'Donovan, K., 2015. Disaster Recovery Service Delivery. Administration \& Society, 009539971562223. doi:10.1177/0095399715622231.

22. Peck, M., Pressman, M. A., 2013. The correlation between burn mortality rates from fire and flame and economic status of countries. Burns, 39(6), 1054-1059. doi:10.1016/j.burns.2013.04.010

23. Sana M.S., 2014. Donating Behaviour in the Nonprofit Marketing Context: An Empirical Study Based on the Identity Theory Model. In: Marketing from information to decision $7^{\text {th }}$ International Conference Proceedings, Cluj-Napoca: Risoprint (pp.230-247), ISSN-L: 2067-0338.

24. Săveanu, T.G., 2011. Forme de participare la viața comunității, complementaritate sau opoziție? Cluj-Napoca: Presa Universitară Clujeană, ISBN: 978-973-595-662-2.

25. Salamon, L.M., 1987. Of Market Failure, Voluntary Failure, and Third-Party Government: toward a Theory of Government-Non-profit Relations in the Modern Welfare State. Journal of Voluntary Action Research, 16, pp.29-49.

26. Schinnerl, M., Greiling, D., 2019. Urban Poverty in Europe - Poverty Reduction Policies and Measures. Review of Applied Socio-Economic Research, 18(2), 118-128.

27. Sinding, S. W., 2009. Population, poverty and economic development Philosophical Transactions B, 364, pp. 3023-3030.

28. Stroe, C., Cojanu, S.-F., 2017. Incidence of Poverty among Large Households and the Alleviating Effects of the Guaranteed Minimum Income in Romania. LUMEN Proceedings, 1, pp. 864-875. https://doi.org/10.18662/lumproc.rsacvp2017.79

29. UN, 2014. Millennium Development Goals Report 2014. United Nations, New York.

30. Van Puyvelde, S., Brown, W.A. 2016. Determinants of Nonprofit Sector Density: A Stakeholder Approach. Voluntas 27, pp. 1045-1063 https://doi.org/10.1007/s11266-015-9656-1.

31. Witesman E. M., 2016. An Institutional Theory of the Nonprofit: Toll Goods and Voluntary Action. Non-profit and Voluntary Sector Quarterly. 45(4):97S-115S. doi:10.1177/0899764016651729. 